\title{
THE DEVELOPMENT OF THE HYMEN.
}

BY

FRED. J. TAUSSIG, M.D.

From the Anatomical Laboratory of Washington University, St. Louis.

With 14 Figures.

Observations thus far collected concerning the origin and derelopment of the hymen may broadly be divided into clinical and embryological. The clinical evidence is based on the study in adult life of the congenital anomalies such as hymen duplex with double vagina, hymen with absent vagina, etc. The interpretation of these anomalies is very difficult, and their value in an embryological study is really only of a confirmatory nature. Consideration of them alone can never result in a solution of the problem of hymeneal development. The embryological evidence on the development of the hymen is based on gross anatomical dissections, single microscopic sections, and on serial sections of the hymen and its surrounding structures. Accurate conclusions must be based on a correct valuation of these three sorts of evidence. For the proper study of so minute a structure as the fetal hymen, the last named method - serial sections - is of paramount value.

An extensive review of the various opinions on hymeneal development has recently been made by Gellhorn ('04). From the standpoint of time, we may distinguish a convaginal theory, according to which the hymen is formed at the same time as the vagina, and a postvaginal theory, according to which the hymen is formed after the development of the vagina. It is, however, better to classify the various views from the standpoint of origin. They may be grouped under four heads:

(1) Vulvar Theory, Pozzi ('84).

(2) Bilamellate Vulvo-vaginal Theory, Schaeffer ('90).

(3) Uni-lamellate Vulvo-vaginal Theory, Nagel ('97), Budin ('79), Webster ('98), Klein ('94).

(4) Vaginal Theory, Dohrn ('75), Veit ('99), Gellhorn ('04). 
(1) Vulrar Theory. Pozzi ('84) bases his theory wholly on the clinical findings in cases of malformation of the genital tract, above all on the presence of a hymen in the absence of the vagina, the occasional occurrence of a urethral hymen, and the presence of a single hymen in double vagina. Such anomalies he believes could only occur if the hymen developed from the rulva or sinus urogenitalis.

(2) Bilamellate Vulvo-vaginal Theory. In 53 out of 190 specimens of fetal hymens (28.8 per cent) Schaeffer (90) was able to find a more or less distinct double hymen. The two folds were connected by bands of tissue, and according to his theory later coalesce to form the hymen. The one fold springs from the vulva, the other from the vagina. Thus we would have a four-layered hymen, two layers from each fold.

(3) Uni-lamellate Vulvo-vaginal Theory. Budin ('799) explains this theory in the following way: The hymeneal ring is the outer end of the vagina. The latter opens into the sinus urogenitalis, at the same time pushing the walls of its canal outwards, just as the portio vaginalis uteri protrudes into the vagina. Thereupon an opening forms in the centre, but the peripheral ring-like protrusion remains, covered externally by the mucosa of the urogenital sinus, internally by the vaginal mucosa. Nagel's ('97) description (Fig. 9) differs only slightly from this. He says: "In embryos of the third month there is an increase and accumulation of the upper layers of the epithelium occurring at first just above the vaginal orifice, whereby the vagina becomes dilated at this point (in embryos of 7-10 cms. length). Through this dilatation arises the hymen. For since the edge of the original opening is not affected by the dilatation, the orifice, on the contrary, retaining its original narrowness, a ring must thereby be formed by which the vagina is shut off from the urogenital sinus. The opening of this ring, up to embryos of $20-22 \mathrm{cms}$. length, remains filled with epithelium."

According to this view, therefore, the hymen is made up of a single fold, one side of which is formed by the vagina, the other by the vulva.

(4) Vaginal Theory. Dohrm's ('/5) work supporting this theory is based on median sagittal sections through the pelvis of twenty-fire fetuses from the ninth to the twenty-eighth week of development. No microscopic study was made. From the ninth to the fifteenth week he finds a stronger growth of the posterior wall of the vagina so that its canal becomes wider and bends more sharply forward. From the seventeenth to the nineteenth week there is a marked proliferation of the inner wall of the ragina, so that it seems made up of tooth-like projec- 
tions. By the beginning of the nineteenth week the hymen is visible as a fold rising from the posterior wall of the vagina directly above the point of entrance of the vagina into the sinus urogenitalis. To meet this a shorter fold from the anterior wall grows downward. The two folds unite, leaving a semi-lunar opening. The growth of the hymen is very rapid. He continues:

"Der Umstand dass die Hymenalmembran in der Nähe der Stelle entsteht an welcher sich die Allantois und Mueller'schen Gänge in der Cloake begegnen, und der Sinus Urogenitalis abscheidet, hat wiederholt zu der Vermuthung geführt, dass der Hymen mit einem Entwickelungsgebilde der früheren Zeit in Zusammenhang stünde. Je genauer man aber die früheren Entwickelungsstufen in ihrer Weiterbildung verfolgt, desto mehr wird man überzeugt, dass ein solcher Zusammenhang nicht vorliegt. Wir haben beim menschlichen Embryo einen langen Zeitraum, den Abschnitt von der 9-1\%ten Woche, in welchem wir den Mittelstufen zwischen Hymen und den an seiner Entwickelungsstelle früher zusammengetroffenen Gebilden nachspüren können. Das Resultat ist negativ. Der Hymen ist lediglich eine spätere Bildung, welche sich nicht in continuirlicher Fortenwickelung an frühere Formen anschliesst."

Gellhorn ('04) also holds to the vaginal theory, although I believe he does not sufficiently emphasize in his article the difference between his conception and the above-mentioned vulvo-vaginal theory. Budin describes the vaginal bulbus as projecting into the urogenital sinus. Into this protruding conus, according to Gellhorn, the raginal connective tissue grows, so that, with the possible exception of a thin layer of epithelium of the urogenital sinus on the outside, the entire hymen is of vaginal origin.

While it is thus seen that there is no lack of theories, their foundation is for the greater part the most meagre and inconclusive evidence. Only one man so far as I know studied serial sections of the hymen microscopically, and that one-Klein ('94)-studied but a single case in this way. ${ }^{1}$ No one has thus far made use of serial sections in a number of embryos of various stages of development for an investigation of the

II do not include in this consideration the two embryos that Filein cut in transverse serial section, but only the one sectioned sagittally. Transrerse sections, unless some sort of reconstruction is made (and this was not done), are not favorable for a study of the hymen in its relations to neighboring structures, a point which Kilein himself concedes. 
hymen. It was this fact that induced me to study the five embryos at my disposal by this method. They were the following:

Embryo 1. $18 \mathrm{cms}$. long, well preserved. No abnormalities of development as far as examined.

Embryo 2. $18 \mathrm{cms}$. long, slightly macerated, no abnormalities.

Embryo 3. $18 \mathrm{cms}$. long, well preserved, normal.

Embryo 4. $21 \mathrm{cms}$. long, removed by laparotomy, excellent preservation. No abnormalities in development.

Embryo 5. Six months gestation. Legs have been removed for another purpose, hence exact length could not be determined. Preserved in Mueller's fluid. No abnormalities of development.

The measurements of these embryos were taken from the vertex to the heel.

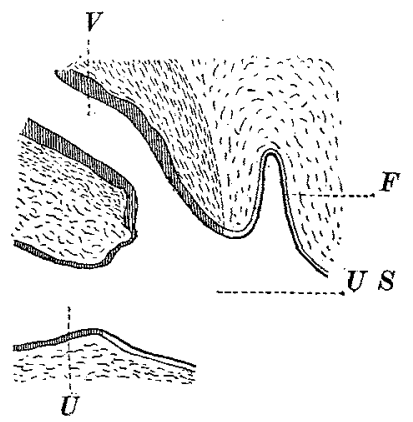

Fra. 1. Median sagittal section at entrance of vagina into urogenital sinus (Embryo 1). It is seen that the fold at the entrance is in connection partly with the vagina, partly with the sinus. F., fold; U., urethra; U. S., urogenital sinus; V., vagina. Magnified $20 \mathrm{X}$.

Paraffin was used in Embryo 1, celloidin in Embryos 2, 3, 4 and 5, as an imbedding medium. All sections were cut sagittally, in series, 25 microns in thickness and were stained, some with van Gieson, some with hematoxylin and eosin.

Before proceeding with the description of the microscopic findings, it will be well to point out the difference between the epithelium of the vagina and that of the urogenital sinus. Sinus epithelium as usually seen in section is a narrow, deeply staining band of small, round or spindle cells, with a nucleus almost filling the cell, whereas vaginal epithelium is a wide mass of large polygonal, faintly staining cells. Only the basal cells of the vagina are small and these take a deeper stain (see Fig. 8a). Klein gives the following measurements: 
Sinus epithelium: thickness of entire layer, $0.063 \mathrm{~mm}$; cells, 13 microns high, 6 microns broad; protoplasmic mantle about one-third the diameter of the nucleus. Vaginal epithelium: thickness of entire layer, $1.75 \mathrm{~mm}$; cells, $1 \%-44$ microns in diameter; nucleus one-fifth the size of the cell. The great variation in size of the vaginal cells is worthy of special attention.

Embryo 1 (Fig. 1). The vaginal canal in this $18 \mathrm{~cm}$. fetus can be seen extending a distance of about one centimeter from the cervical indentation to the point where it breaks into the vulva. In its upper four-fifth there is no lumen, the central portion being occupied by an irregularly branching trunk of epithelium, four or five cells in diameter. In the lowest one-fifth the canal suddenly widens, the mass of epithelial cells becomes much thicker and a lumen is to be seen that is partly filled with desquamated epithelium. Beneath this epithelial layer lies an area of loose connective tissue cells possessing an embryonal character, with only here and there a connective tissue fibre stained pink by the fuchsin. This layer of embryonal cells is several times thicker than the rod of epithelium in the centre. The outer covering of the vaginal cylinder consists of a thin mantle of connective tissue fibres whose red color, when stained with van Gieson, serves to outline it sharply from the surrounding structures.

The point where the vaginal cylinder enters into the urogenital sinus can be followed in nineteen sections. The vaginal conus bends ventrally at its point of entrance into the sinus and thereby a fold is formed between its dorsal wall and the sinus. Microscopically this fold can be seen to consist of the following structures from within outwards: (1) vaginal epithelium, (2) vaginal embryonal connective tissue, (3) fully formed connective tissue fibres from the vagina, (4) fully formed connective tissue fibres from the vulva, (5) vulvar or sinus epithelium. This fold is, therefore, of vulvo-vaginal origin. It corresponds in shape and position to the hymen.

Embryo \& (Fig. 2). Fetus $18 \mathrm{cms}$. long. Owing to the poor state of preservation the epithelium is partly cast off and the hematoxylin stain rather diffuse. In general the state of development approximates that described in Embryo 1. A vaginal lumen can be seen, but it seems to be an artifact due to the desquamation of epithelium. There is no proliferative tendency in the vaginal connective tissue. The bulk of the vaginal conus is composed of embryonal connective tissue cells. The growth along the posterior vaginal wall is less marked, so that the fold 
left at the point of entrance into the sinus is less pronounced. However, such a fold can be distinctly followed through a considerable number of sections. From the direction of the connective tissue fibres it can be seen that both vulva and vagina enter into its composition.

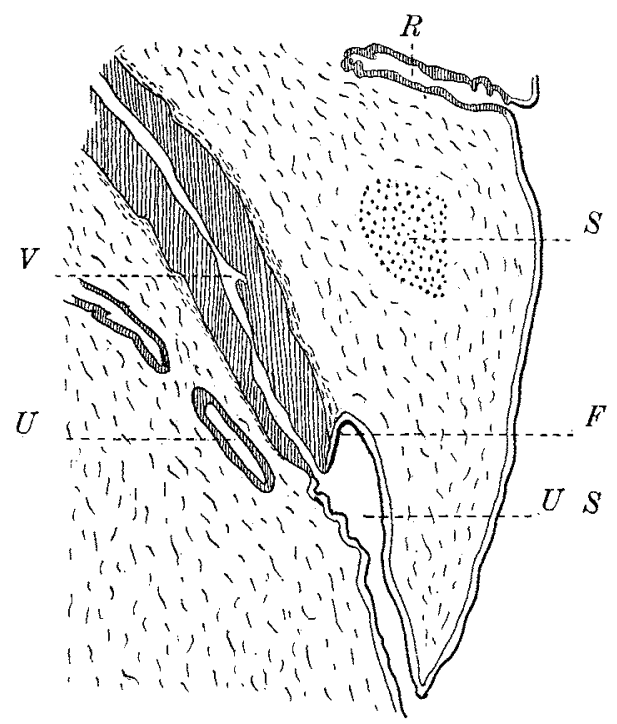

FIg. 2. Median sagittal section through lower portion of genital tract (Embryo 2). F., fold; R., rectum; S., sphincter ani muscle; U., urethra; U. S., urogenital sinus; Y., ragina. Magnified $20 \mathrm{X}$.

Embryo 3 (Fig. 3). Fetus $18 \mathrm{cms}$. in length, good state of preservation. The three layers of the vagina previously described are here also to be seen in about the same stage of development. No raginal lumen can be distinguished. The conrex bulb of the vaginal cylinder projects but slightly into the cavity of the sinus urogenitalis. There is no special growth of the posterior wall, and nowhere is there to be seen any fold ${ }^{2}$ such as was found in Embryos 1 and 2 . There is no proliferation of the vaginal connective tissue.

${ }^{2}$ Since the completion of this article, I was able to obtain a sixth embryo and made serial sections of the genital tract. The embryo was $18 \mathrm{cms}$. in length and in an excellent state of preservation. The conditions were similar to those of Embryo 3. The ragina consisted mostly of embryonal connective tissue, with a central, somewhat branching core of epithelium, a few cells in thickness. At the point of its entrance into the sinus urogenitalis, there was no sign of a connective tissue fold such as Nagel describes (Fig. 9). 
Embryo 4 (Figs. 11-13). Fetus $21 \mathrm{cms}$. in length. The vagina is seen to possess a lumen in its lower half, this lumen being filled almost entirely with desquamated epithelial cells, whose nuclei and protoplasm, though greatly shrunken, can still be differentiated. The three layers of the vagina differ greatly in character from those described in Embryos 1-3. The inner epithelial layer is here the thickest of the three. The cells lie 12-15 rows deep and differ in size and staining character in a way similar to that of the adult vagina; $i$. e., the superficial cells are large, somewhat spindle-shaped, their protoplasm and

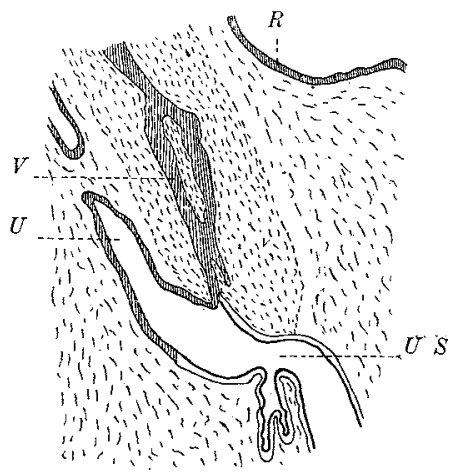

FIG. 3. Median sagittal section through entrance of ragina into urogenital sinus (Embryo 3). No fold is here visible. $R$., rentral wall of rectum; U., urethra; r., ragina; U. S., urogenital sinus. Magnified $20 \mathrm{X}$.

nucleus staining faintly; the deeper cells, especially the basal layer, are sinall, cubical, with deeply staining nucleus and scanty protoplasm. Into the layer of loose connective tissue cells outside this epithelial layer the latter sends finger-like processes, so that at times apparent islands of connective tissue cells are seen to lie in the midst of the epithelium. In serial sections these can be seen to be continuous with the connective tissue layer. Judged by the pictures in the previous cases, it would seem more rational to interpret this intertwining of connective tissue and epithelial process as due to an outward growth of the epithelium rather than an inward growth of the connective tissue.

The inner connective tissue layer is not as wide but more dense than in the embryos just described. The nuclei are smaller and stain more deeply, and here and there beginning connective tissue fibrillæ are to be noted. The outer layer of connective tissue is not clearly differentiated 
from surrounding structures. We find the connective tissue fibres more developed and an admixture of unstriped muscular fibres.

Following the vagina down to its point of entrance into the sinus urogenitalis, we are struck by the difference in size and staining property of the vaginal and sinus epithelium. The sinus epithelium at this point consists of three or four layers of small cubical cells with deeply staining nucleus. This difference in the epithelium, already emphasized by Klein, together with the direction of the connective tissue fibres, makes it easy to determine how much is vagina, how much is sinus.

It is seen in studying the series that a crescentic fold of tissue attached to the dorsal and lateral aspect is left at the point of entrance of vagina into sinus. This fold is lined on the inner side by vaginal, on the outer side by sinus epithelium (Fig. 12). It is not by any means a well-formed membrane.

Just anterior to this fold the connective tissne of the vagina both ventrally and dorsally (but principally dorsally) sends a proliferating branch in through the epithelium. The two join to form a membrane that, with the exception of one small opening, completely closes the vaginal canal. It is clear that this membrane must be the hymen, and it is also indisputable that, in this case at any rate, it is of raginal origin, since it lies internal to the point of junction between vagina and sinus urogenitalis, is lined on both sides by vaginal epithelium, and has its connective tissue directly continuous with the connective tissue of the vagina.

That this membrane is not one of the secondary folds occasionally to be seen internal to the hymen, where there is a marked proliferative tendency on the part of the raginal connective tissue, is evident by the fact that (with this one exception) there are to be seen no high papillary projections. The sections in this case seem to represent about the same stage of development as do those of Klein, but his interpretation of the findings is different, as will be subsequently shown.

Embryo 5 (Figs. 4-8). Development that of about 5-6 months. The vagina is $3 \mathrm{cms}$. in length and from $2-6 \mathrm{mms}$. in diameter. The narrowest portion is the upper fifth, in which there is no lumen and the epithelium is only a few layers of cells in thickness. Here there is also little connective tissue proliferation. Further down the canal, and particularly near the vulvar end, this proliferation is very extensive, so that there appear bands, papillæ and islands, depending on the way the sections happen to be cut through the projections. Here we should 
be at a loss to interpret the varions structures were it not that we are able to follow them in series and thus to determine their relationship to their surroundings. Only two layers can be differentiated in this specimen, the middle layer of embryonal connective tissue being absent. 'The epithelial layer is similar to that in Embryo 4, except that larger'

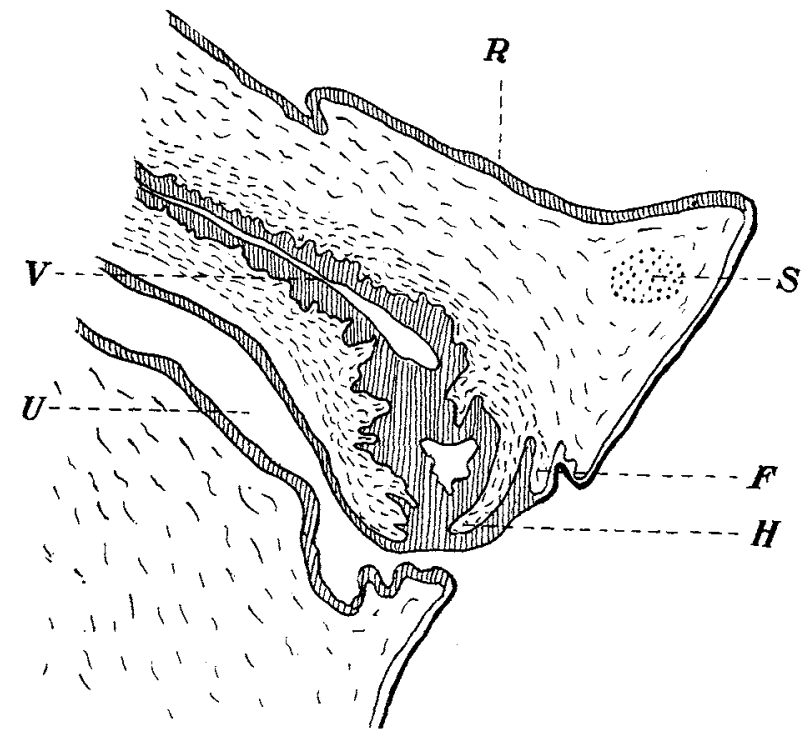

Fig. 4. Sagittal section a little to right of median line through lower genital tract (Embryo 5). Section No. 179. F., fold; H., hymen; R., ventral wall of rectum; S., sphincter ani muscle; U., urethra; V., vagina. Magnified $5 \mathrm{x}$.

quantities of desquamated cells are found lying in the vaginal lumen. The connective tissue fibres take the fuchsin stain decply and are morc densely compacted than in Embryo 4.

We can again distinguish two folds or membranes. The outer fold is lined externally by vulvar epithelium, internally by vaginal epithelium (Fig. 8a). Its connective tissue fibres (Fig. 8) are partly continuous with the connective tissue of the vagina. In part they intermingle with the connective tissue of the vulva and perineum. Reconstructed, this fold has somewhat the shape of a thin crescent, whose concave margin faces the urethra. It springs almost wholly from the dorsal wall. A short projection can be seen opposite on the ventral 
wall. Directly anterior to this fold is the true hymen, a membrane two to three millimeters in height and about one-half to one millimeter in thickness, likewise springing mainly from the dorsal wall (Figs. 4 and 5), with a smal oval opening high up near the urethra corresponding to the hymeneal orifice. Its epithelium and connective tissue are vaginal. Papillary proliferations are found on its inner and outer surfaces.

The evidence of these five embryos can be briefly summarized as follows:

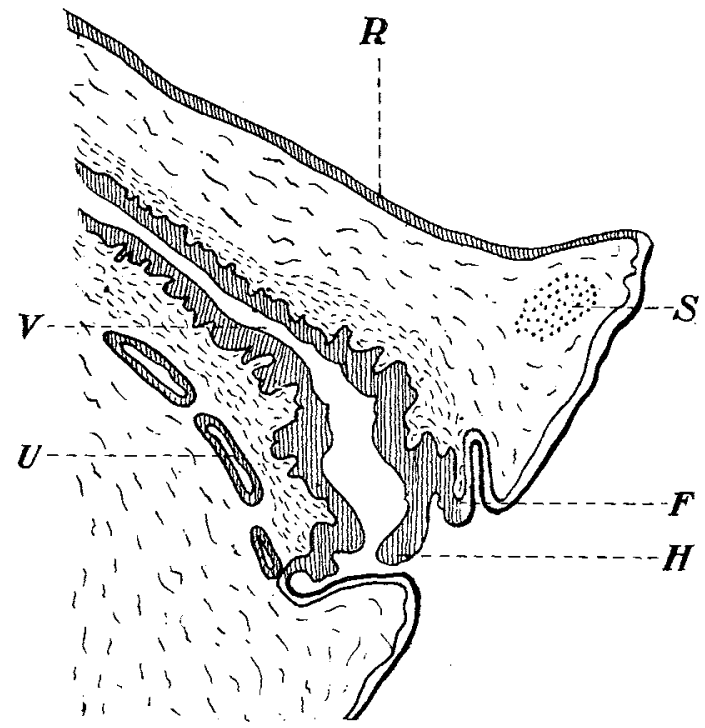

Fig. 5. Median sagittal section (Embryo 5 ). Section No. 187. F., fold; H., hymen; R., rentral wall of rectum; S., sphincter ani muscle; U., urethra; $\Gamma$., vagina. Magnified $5 \mathrm{X}$.

In the fetus $18 \mathrm{cms}$. long (Embryos 1 and 2 ) there may be seen at the point of junction of ragina and sinus urogenitalis, rising mostly from the dorsal wall, a crescentic fold composed of elements coming both from the vagina and the vulva or sinus urogenitalis. Occasionally, as in Embryo 3, this fold is absent. In the fetus $21 \mathrm{cms}$. long this crescentic fold is again to be seen, but not so well marked. Anterior to it and lying wholly within the ragina is a thick membrane, the hymen, almost completely closing the vaginal canal, composed only of vaginal elements. No other similar folds or membranes are present.

In the fetus $25-30 \mathrm{cms}$. long the crescentic vulvo-vaginal fold is still recognizable, but the true hymeneal membrane is evidently anterior to 
it. It is here very well developed and is composed entirely of vaginal elements.

The explanation that suggests itself from the study of my sections is similar to Dohrn's ('75). It points to the hymen as of vaginal origin, independent of the place at which the vagina breaks into the urogenital sinus. ${ }^{3}$ This spot is already clearly to be seen in the $14 \mathrm{~cm}$. fetus as shown in Nagel's illustration (Fig. 9). Within arises a fold of vaginal tissue, the true hymen, stretching almost completely across the vaginal canal. At the point where the vaginal bulbus breaks through,

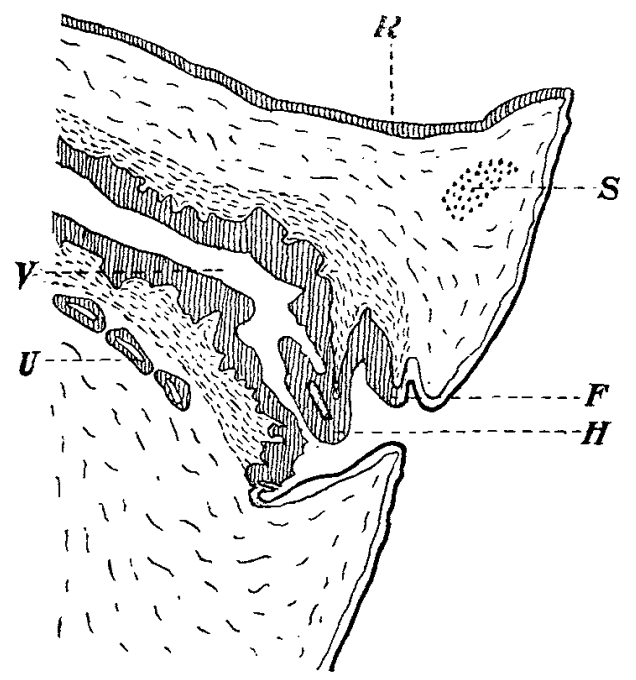

Fig. 6. Sagittal section a little to left of median line (Embryo 5). Section No. 191. F., fold; H., hymen; R., ventral wall of rectum; S., sphincter ani muscle; U., urethra; V., vagina. Magnified $5 \mathrm{X}$.

the so-called Muellerian eminence, a more or less well marked fold of tissue is left. As the fetus develops this fold becomes obliterated. In cases of arrested development we may have the fold persisting almost to birth, thus giving the picture of a bilamellate or double hymen.

${ }^{3}$ In this and subsequent arguments $I$ have assumed that the vagina is entirely formed by the coalesced Muellerian ducts and not to any extent by the sinus urogenitalis. Practically the only testimony that would speak against this view is the occasional presence of epithelial areas that appear to come from the urogenital sinus. The interpretation of such epithelial areas is, however, a matter of great uncertainty, as has recently been pointed out by Meyer ('07) in a discussion on the remnants of the Wolffian ducts. 
Let us now see how this explanation agrees with the findings, clinical and microscopic, that have been brought forward by other observers.

Considering in the first place the clinical evidence, we would emphasize the variations in the shape of the hymeneal orifice. This has, I believe, not been given due importance. We have on the one hand authors as Nagel ('97) and Klein. ('94), who hold that the formation of the hymen is passive, $i$. e., merely due to a bulging forward of the vaginal bulb, particularly of the dorsal wall, into the urogenital sinus, and a consequent thinning out of the intervening septum. On the other

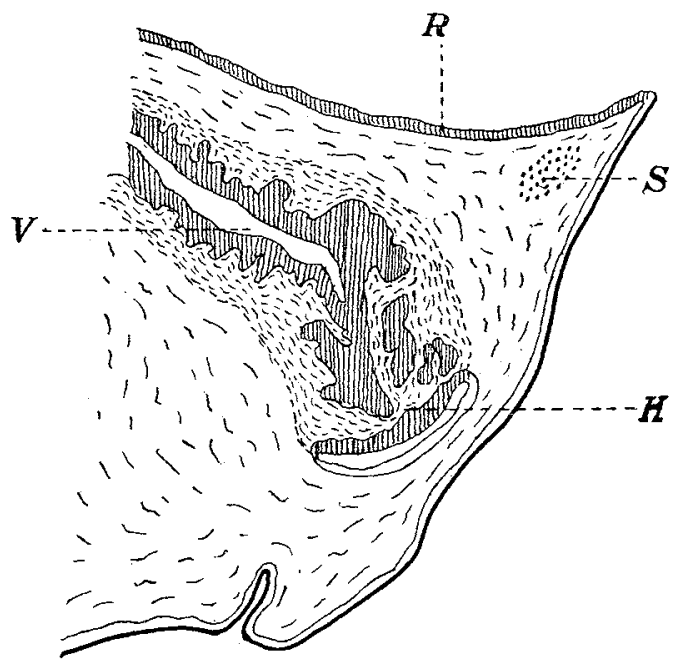

Fit. T. Sagittal section about $1 \mathrm{~mm}$. to the left of plane of Fig. 6 . Urethra and vulvo-vaginal fold are not to be seen in this section, No. 207. H., hymen; R., ventral wall of rectum; S., sphincter ani muscle; V., vagina. Magnified $5 \mathrm{X}$.

hand, some investigators, as Dohrn ('75) and Schaefer ('95), consider its formation as active, $i$. e., a proliferation of connective tissue with the production of a membrane more or less completely shutting off the vagina from without. It seems to me the variations in position, shape and size of the hymeneal orifice point distinctly to a proliferative process. If we conceive the evolution as passive, we should expect a round or oval orifice near the upper portion of the hymen. Such a view cannot explain the cases of denticulate, cribriform and fimbriate hymens. Even Klein takes for granted, in the last named form, a papillary growth along the edge of the hymen. In other words, he claims the process is 
passive except when it is active. This seems irrational. Apparently the hymen does not represent a thinned out membrane, but a proliferation of connective tissue. That such a proliferating tendency of the vaginal connective tissue exists, all writers, including Klein ('94), agree.

The next clinical fact to be considered is that occasionally a hymen is to be found in the absence of a vagina. This point is emphasized by

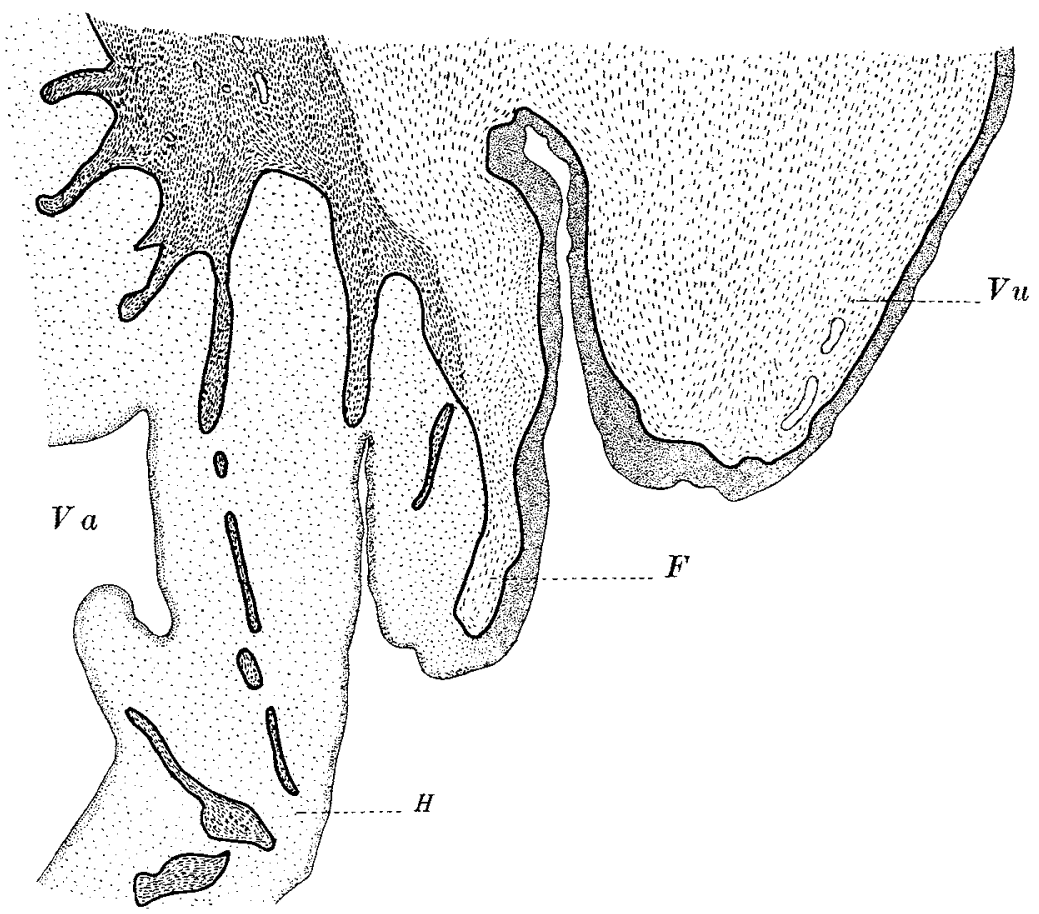

FrG. 8. Drawing of dorsal portion of hymen, vulva and vagina in median sagittal section (Embryo 1). Section No. 183. This shows clearly how the vulvo-vaginal fold is distinct from, and posterior to, the hymen. By their density and direction, the connectire tissue fibres of the ragina are sot off from the vulvar connective tissue. The difference in epithelium is also indicated in a general way. F., fold; H., hymen; Va., vagina; Vu., vulva. Magnified $40 \mathrm{X}$.

Pozzi ('84), as fayoring his conception of the vulvar origin of the hymen. It is, however, here as elsewhere that the exception proves the rule. In the large majority of cases where the vagina is absent, a hymen is also not to be found. Thus the weight of the evidence favors the vaginal theory. Furthermore, as Veit points out, the occurrence of 
a hymen in atresia vaginæ can be readily explained. We know that, at some places, portions of the vagina may remain obliterated while at other points a lumen is formed. If the extreme lower end of the vagina be the only portion that so develops it might readily present the picture of a hymen in absence of the vagina.

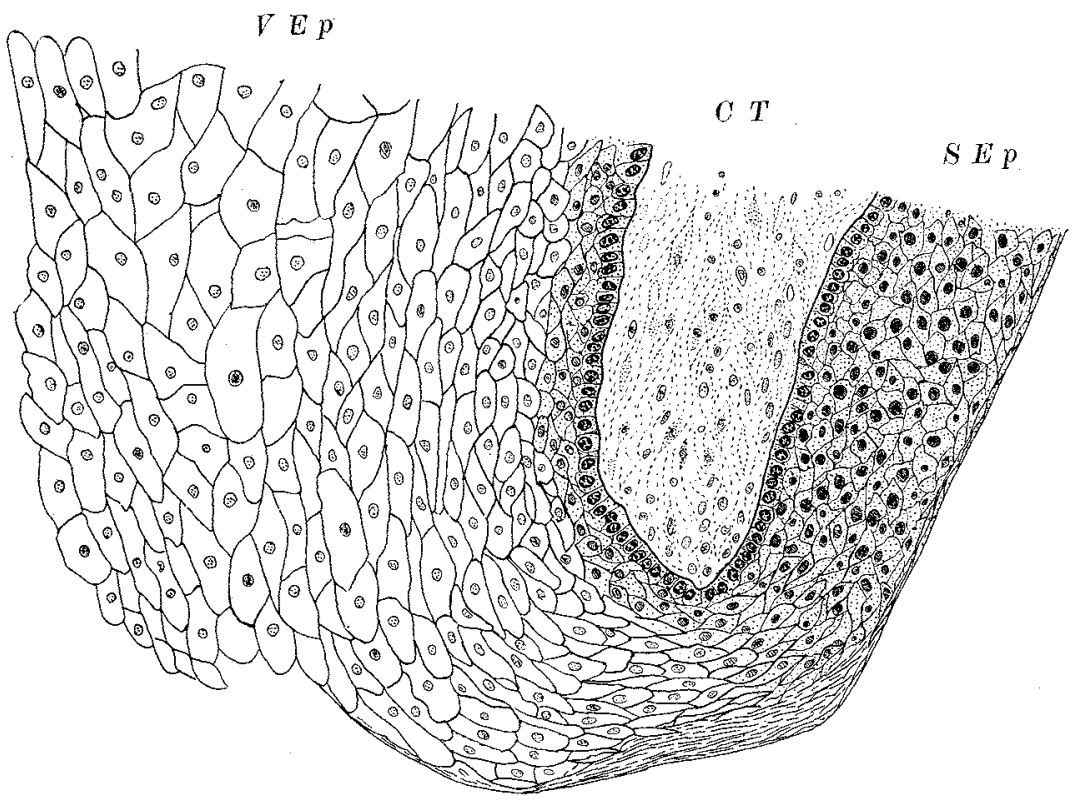

Frg. 8a. Detail drawing ot the tip of the vulvo-vaginal fold seen in Fig. 8 to show the difference in character between vaginal epithelium and sinus epithelium. C. T., connective tissue ; V. Ep., vaginal epithelium; S. Ep., sinus epithelium. Magnified $100 \mathrm{X}$.

A few cases have been reported in which a single hymen was found with double ragina. This fact is brought forward by the upholders of the vulvar theory as proof of their contentions, in spite of the fact that here, too, the rule is that the hymen is double, one for each vagina. The burden of proof is here likewise against them. The unusual cases of single hymen can, moreover, be readily explained on the basis of an incomplete vaginal septum, that is, one in which the septum dividing the two vaginas does not fully reach to the hymeneal ring.

From the anatomical dissection of 190 specimens of fetal hymens Schaeffer ('90) concluded, as already stated, that this structure was composed of two folds. Gellhorn ('04) has raised the objection to these 
investigations that they were based upon pathological material. According to Schaeffer's own statement 42 per cent of his cases showed some maldevelopment of the genital tract. When we consider what we mean by maldevelopment, Schaeffer's cases acquire a distinctive value of their own. We mean not a different method of development, but an arrest of development. ${ }^{4}$ If in 42 per cent of his specimens there was arrest of development in other portions of the genital tract, we have a right to

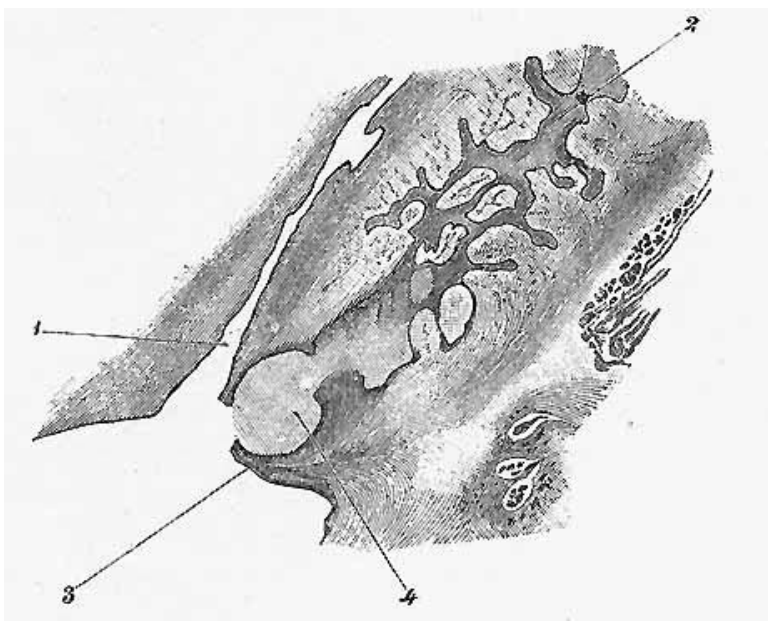

Fic. 9. Sagitial section throngh the posterior end of the vayma of a human cubrgo of $14 \mathrm{~cm}$. body length ( Nigel). 1, urethra; 2, rasina; 3, posterior surface of the hymen; 4 , widened prtion of the ragina immediately back of the hrmen.

expect a rather large percentage to show an arrest of hymeneal development. Now Schaeffer found in 28.8 per cent of all cases a bilamellate hymen, whereas other investigators-Klein ('94), Hart ('02), Gellhorn ('04)-found bilamellation but rarely or not at all. Is the inference not justifiable that the additional lamella represents a membrane left by some previous step of development that persisted instead of becoming obliterated? But what membrane could that be? Only the membrane

${ }^{4}$ It is of interest in this connection that the hymen, according to Nagel, appears as a membrane only in the human race. In elephants, hyenas and other quadrupeds there is usually a constriction at the point of entrance of vagina into sinus urogenitalis, but no true lymeneal membrane. Corresponding to this constriction, we have at this point in man the vulvo-vaginal fold. 
left at the point where the vaginal bulbus breaks into the sinus urogenitalis. It is this vulvo-vaginal fold, I believe, so clearly to be seen in my specimens, that in Schaeffer's cases persisted to a later date in a number of instances and gave the appearance of an additional fold of the hymen. This assumption is further supported by the following table in Schaeffer's work:

\begin{tabular}{rlcc} 
Length of Fetus. & \multicolumn{4}{c}{$\begin{array}{c}\text { Number of } \\
\text { Specimens. }\end{array}$} & $\begin{array}{c}\text { Bilamellate } \\
\text { Hymen. }\end{array}$ & Percentage. \\
$16-25$ cms. $\ldots \ldots \ldots \ldots \ldots \ldots \ldots$ & 9 & 5 & 55.5 \\
$26-30$ cms. $\ldots \ldots \ldots \ldots \ldots \ldots \ldots$ & 8 & 4 & 50. \\
$31-35$ cms. $\ldots \ldots \ldots \ldots \ldots \ldots \ldots$ & 26 & 10 & 38.5 \\
$36-40$ cms. $\ldots \ldots \ldots \ldots \ldots \ldots \ldots$ & 41 & 15 & 36.6 \\
$41-45$ cms. $\ldots \ldots \ldots \ldots \ldots \ldots \ldots$ & 58 & 15 & 24.1 \\
Over 45 cms. $\ldots \ldots \ldots \ldots \ldots \ldots \ldots$ & 28 & 4 & 14.3
\end{tabular}

The steady decrease in the percentage of bilamellate hymen as the state of development increases is very striking and certainly would incline one to the belief that the bilamellate hymen represents a more primitire stage of development.

So much for the clinical and gross anatomical evidence on this subject. Coming now to the microscopic investigations, we must put aside as of secondary value all those based on fetuses previous to the fifth month of development, at which time the hymen, according to the consensus of opinion, first makes its appearance. ${ }^{5}$ This would include Nagel's ('97) sections of a $14 \mathrm{~cm}$. fetus (Fig. 9) which gives pictures of a vulvoraginal septum similar to that found in my Embryos 1 and 2 . In the series of sagittal sections of a $26 \mathrm{~cm}$. fetus studied by Klein ('94) (Fig. 10) we have valuable evidence. A comparison of his illustrations with mine are very interesting. He finds a vulvo-vaginal fold that he interprets as the hymen at the point of junction of vagina and urogenital sinus. Just anterior to this fold and extending from both ventral and dorsal walls is a fold considerably thicker than the so-called hymen. Klein's explanation of this fold is that it is a column of vaginal tissue such as we occasionally find in hymen columnatus. Neither in his pictures nor in his description has Klein proven this, and a priori it is

${ }^{5}$ This excludes the work of Berry IMart ('02), who argues from the serial sections of two embryos of three months development that the hymen is formed from the Wolffian ducts. Webster ('98) has clearly pointed out the fallacy of his conclusions. 
difficult to see how such an explanation is possible. In a sagittal median section through a hymen columnatus we should expect to find the column as a broad surface continuous with the hymen. In Klein's sections it is comparatively narrow and there is a considerable hiatus between the column and hymen. A more plausible explanation would be that the so-

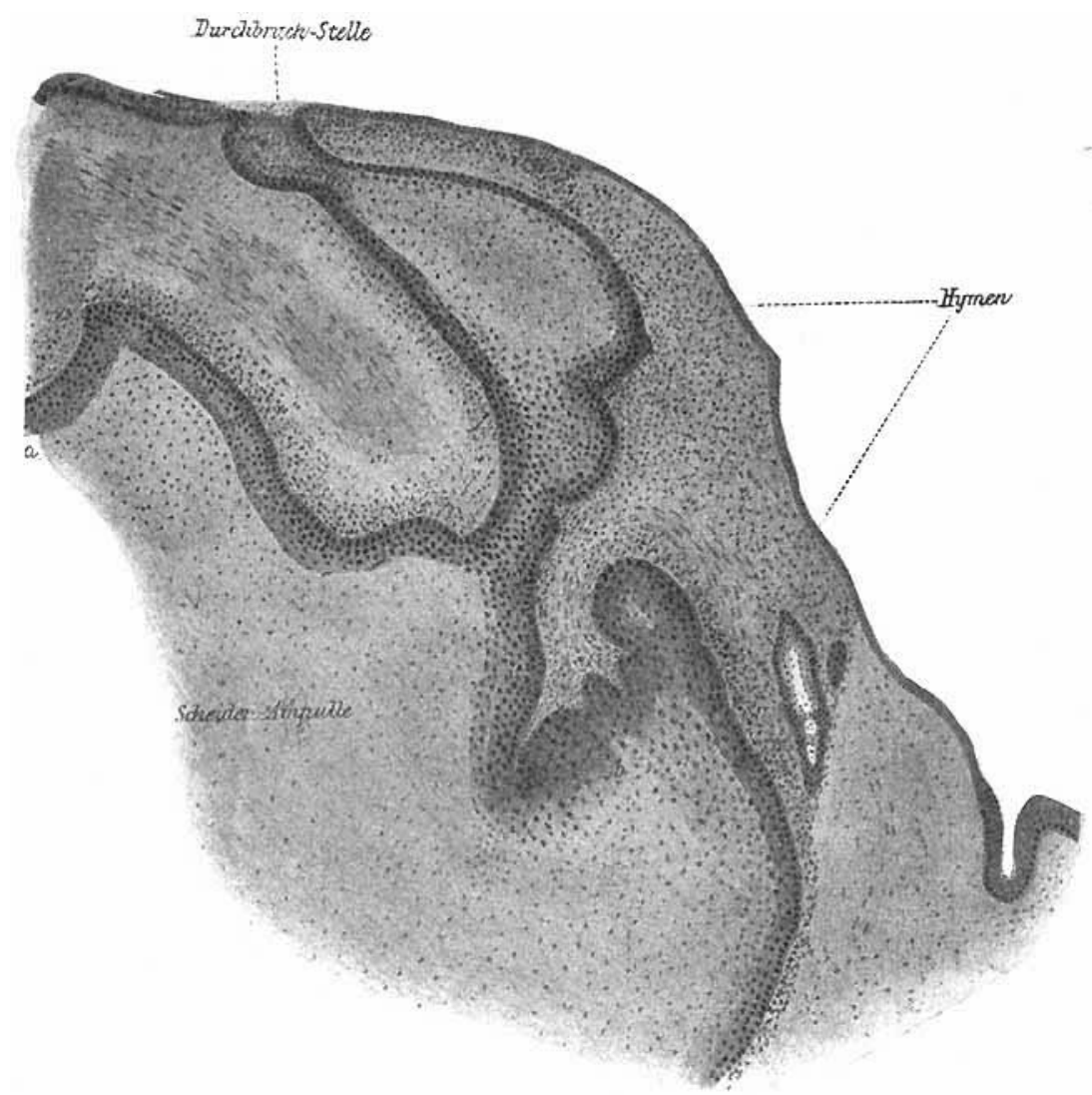

FIa. 10. Sagittal section of the posterior end of the vagina and the hymen (after Klein). Of the two folds Klein interprets the left hand one as a columnar branch of the right hand one, the hymen. Magnified $60 \mathrm{X}$.

called column is one of the secondary folds or papillæ occasionally found in the vagina back of the hymen. These secondary proliferations are, however, found primarily in later stages of fetal development when there is a general proliferative tendency in the entire lower vagina. In Klein's embryo there is no such general reduplication of vaginal connective tis- 
sue. There are really only the two folds, just as in my sections, the one vulvo-vaginal, the other vaginal; the former a thin septum, the latter a thick membrane. In the absence of contradictory evidence, I feel justified in considering Klein's case as rather supporting than opposing my views.

The character of the epithelial covering also gives support to the vaginal theory. Klein lays stress on the marked differences between the vaginal and the vulvar epithelium. Gellhorn's ('04) microseopic sections of seven hymens at various stages of fetal development show that vaginal epithelium lines both sides of the hymen.

The direction of the hymeneal connective tissue fibres has been emphasized by Gellhorn ('04) as being of considerable importance. Even in fetuses at full term they could be seen running parallel and continuous with the vaginal connective tissue fibres. From the vulva no fibres enter into its composition.

I am well aware that the evidence of the serial sections in these five embryos is insufficient to firmly establish my contentions. Further investigations are necessary. Unfortunately, the material in a fresh state is not easily collected. Progress in this question can, however, only be made by the study of serial microscopic sections of the lower genital tract in fetuses of $18-30 \mathrm{cms}$. length.

Evidence of the sort that has heretofore been employed to support theories of hymeneal development, even if absolutely contradictory, cannot invalidate the views expressed in this paper. It would require evidence of the same character, serial sections of a number of embryos, to do this. Until such evidence is at hand, therefore, we must consider the hymen as a vaginal structure formed in the fifth month of fetal life by connective tissue proliferation directly anterior to the point where the vagina enters into the urogenital sinus.

In conclusion, I wish to thank Dr. R. J. Terry, Professor of Anatomy at Washington University, for assistance in getting material for this work and many helpful suggestions; also Dr. H. P. Wells for his excellent micro-photographs.

\section{LITERATURE.}

ACKEREN, F. VAN. 1888. Beiträge zur Entwickelungsgeschichte der weiblichen Sexual-organe des Menschen. Zeitschrift f. Wissen. Zool., Vol. XLVIII.

BAYER, H. 1903. Entwickelungsgeschichte des weiblichen Genitalapparates. Vorlesungen iiber Allg. Geburtshilfe, Vol. I, Part 1, Strassburg. 
Budin, P. 1879. Recherch. sur l'hymen et l'orifice vaginal. Prog. Med., p. 677 .

Buerler, A. 1905. Die Entwickelungsgeschichte der Keimdrisen und ihrer Ausführungsgänge. Hērtwig's Handb. d. Entwick. d. Wirbelthiere, Part III, Chap. 2.

DEBIERRE, CH. 1886. Sur l'anatomie de l'oridnct. Ass. Fr. pour l'avanc. des sci., Part 2, p. 540.

Diominsor, R. L. 1904. Urethral Labia or Urethral Hymen. American Medicine, Vol. VII, No. 9.

DoHrn, F. A. R., von. 1884. Die Bildungsfehler des Hymens. Zeitschrift t. Geb. u. Gyn., Vol. XI.

Dohrs, F. A. R., voN. 1875. Ueber die Entwickelung des Hymens. Schriften d. Ges. z. Beförd. đ. ges. Naturwiss. z. Marburg, Vol. X, Suppl. Part 1.

FencrNa, H. 1893. Lehrbuch der Frauenkrankheiten, Stuttgart.

Gellfions, G. 1904. Anatomy, Pathology and Development of the Hymen. Amer. Journ. Obst., Yol. L, No. 2, pp. 145-178.

HART, BERry. 1902. The Development of the Urino-genital Tract. Brit. Med. Journ., Sept. 13.

HoffmaNi, C. K. 1896. Artikel iber "Hymen" in Eulenburg's Encyclopedie, Vol. XI, p. 178.

Joв. 1898. De l'hymen en rapport avec l'accouchements. Thèse, Nancy, No. 4.

KEMPE, H. A. E. 1904. Beiträge zu einer Entwickelungstheorie des Hymens, Compt. rendu du Cong. Intern. de Zool., Bern, 1904, Bale, 1905, pp. 315-318; rev. in Jahresber. $u$. d. Fortsch. d. Anat. u. Entwick., Vol. XI, Part III (1).

KLEIN, G. 1894. Entstehung des Hymens. Festschrift zur Feier des fünfzigjährigen Jubiläums der Gesellschaft für Geburtshilfe und Gynäkologie, Wien.

Koelcmer, A. 1879. Manual of Human Microscopic Anatomy, p. 465.

Meyer, R. 1907. Zur Kenntniss der kranialen und kaudalen Reste des Wolff'schen Ganges u. s. w., Zentralbl. f. Gyn., Vol. XXXI, p. 293.

Mikazkovicz, G., voN. 1885. Untersuchungen über die Entwickelung des Harn- und Geschlechtsapparates dex Amnioten. Intern. Monatschr. $f$. Anat. u. Histol., Vol. II, p. 41.

Mrnot, C. S. 1892. Human Embryology, New York.

NAGELL, W. 1896. Die Weiblichen Geschlechtsorgane, in v. Bardeleben's Handbuch der Anatomie des Menschen, Part 2, Jena.

NAGEL, W. 1897. Die Entwickelung und Entwickelungsfehler der Weiblichen Genitalien, in Veit's Handbuch der Gynäliologie, Vol. I, pp. 521561.

NAGEL, W. 1891. Ueber die Entwickelung des Uterus und der Vagina beim Menschen. Arch. f. Microse. Anat., Vol. XXXVII. 
Porrer, P., et Charpy, A. 1901. Traité d'Anatomie Humaine, Vol. V, pp. 549-555.

Pozzi, S. 1884. De la bride masculine du vestibule chez la femme et de l'origine de l'bymen. Annales de Gynec., Vol. XXI, p. 268.

RetTeRer, E. 1891. Sur le developpement comparé du vagin et du vestibule des mammifères. Compt. Rendu. Soc. Biol., Vol. III, p. 291.

SCHAEFEER, O. 1890. Bildungsanomalien der weiblichen Geschlechtsorgane. Arch. f. Gynäk., Vol. XXXVII, p. 199.

Strobel. 1898. Entwickelung und Anatomie der Vagina, Urethra und Vulva. Inaug. Diss., Würzburg.

Tourneux, F., ex Legaye, Ch. 1884. Mêmoire sur le developpement de I'uterus et du vagin. Joum. de l'Anat. et de la Phys., Vol. XX, p. 330.

VEIT, J. 1899. Handbuch der Gyü̈kologie, Kapitel über "Die Erkrankungen der Vulva," Vol. III, p. 189.

WaLDEXer, W. 1899. Das Becken, p. 654 .

Websten, J. C. 1898. Some Observations regarding the early Wolffian and Muellerian Ducts, with Remarks concerning the Hymen. Trans. Amer. Gyn. Soc., p. 446.

Werthelmer, E. 1883. Recherches sur la structure et la developpement des organes génitaux externes de la femme. Journ. de l'Anat. et de la Phys., Vol. XIX, p. 551 .

Frgs. 11-13. Sagittal sections through the hymen (Embryo 4). The dotted line is drawn at the level of the entrance of the vagina into the urogenital sinus. It is to the left of this that the hymen is formed. Fig. 11 (Section No. 61) strikes about the centre of the hymen, so that it appears as folds from above and below that do not meet (hymeneal orifice). To the right of it lies a high, narrow fold, rising from below, lined on the left (anterior) side by vaginal, on the right (posterior) side by sinus epithelium. In Fig. 12 (Section No. 63) the exact position of this fold and its relations can be better seen. The hymen can be clearly recognized to the left of it as a connective tissue membrane lined on both sides by vaginal epithelium. This is the most convincing picture in the series. Fig. 13 is taken lateral to this (Section No. 67). Only a teat-like remnant of the vulvo-vaginal fold can be seen below and to the right. The bymen is seen as a thick band. Papille appear on the posterior side. Magnified $45 \mathrm{X}$. 
THE DEVELOPMENT OF THE HYMEN

F. J. TAUSSIG

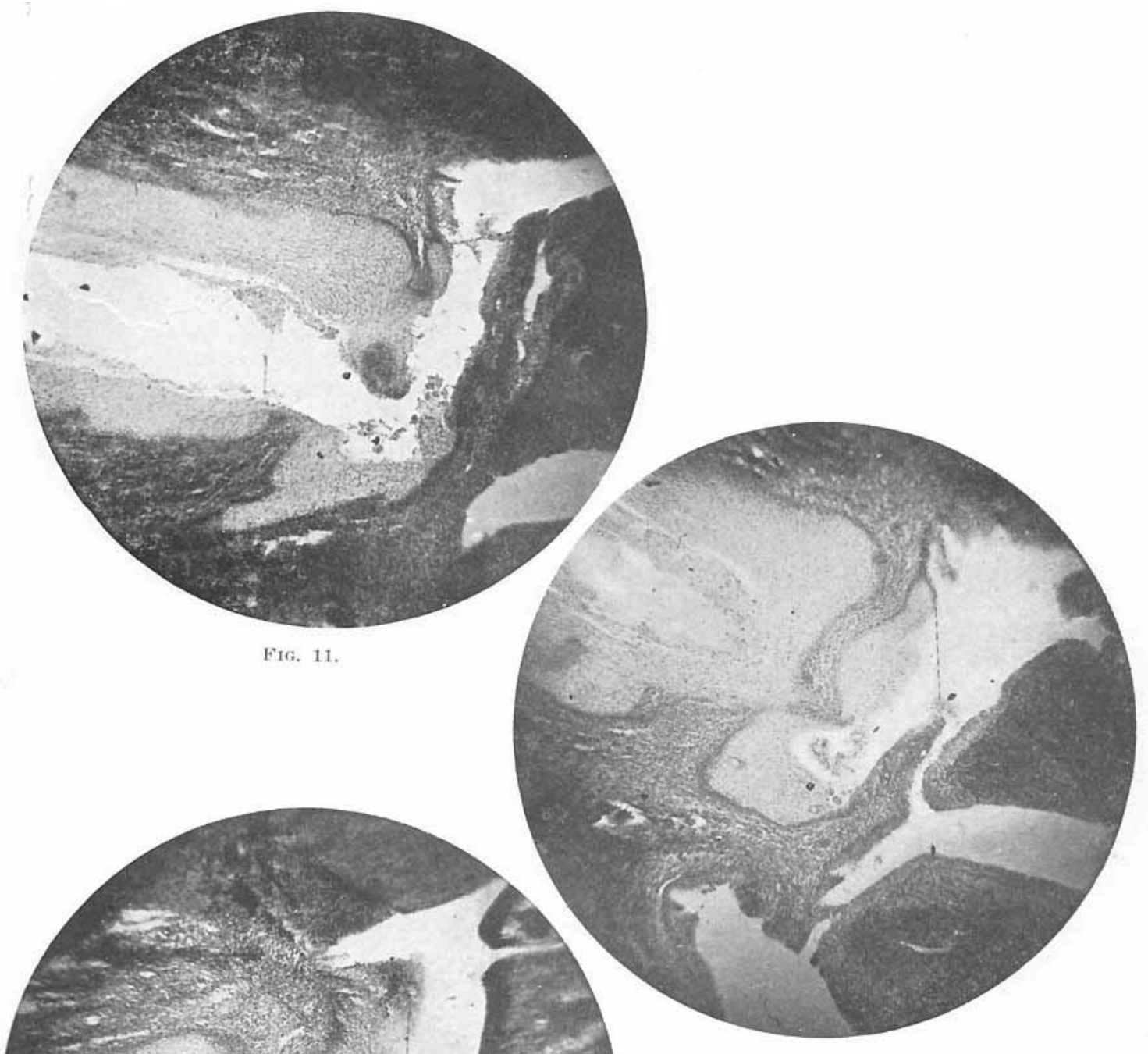

FIG. 12 .

IIIG. 13. 